\title{
Social Media Use by the Rohingya Refugees in Bangladesh: A Uses and Gratification Approach
}

\author{
Tania Nachrin ${ }^{1}$ \\ ${ }^{1}$ Humanitarian Worker and Independent Researcher, Bangladesh \\ Correspondence: Tania Nachrin, 1288/A Rasheda Villa, $4^{\text {th }}$ Floor/5A, Hajee Chand Mia Road, Chandgaon-4112, \\ Chittagong, Bangladesh.
}

Received: September 30, 2019

Accepted: November 1, 2019

Available online: November 14, 2019

doi:10.11114/ijsss.v8i1.4551

URL: https://doi.org/10.11114/ijsss.v8i1.4551

\begin{abstract}
The refugee crisis is one of the greatest problems in the world right now. Countries from both developed and developing parts of the world have faced this crisis for many years. Usually, refugees lost their home-relatives, income source and all meaningful aspects of life. Living in another country with the help of the foreign government and NGOs, the refugees spend a challenging time under many difficulties. This study concentrates on social media uses of the Rohingya refugees in Bangladesh under the light of uses and gratification theory. The purposive sampling technique used to collect the data. This study focuses on what are the main reasons for using social media, attitude toward social media, and lastingness on social media by the Rohingya refugees. Data has been collected from 37 Rohingya refugees ranging in age of 19 to 32 years, gendering both male and female. Results indicate that Facebook is the most preferred social media. The majority of them $(37.8 \%)$ are using social media for one to two years, $(43.2 \%)$ of them are most active on social media at 7-8 PM and spend four to five hours each day. $62.2 \%$ of the respondents have only one social media account. The majority (32.4\%) of the Rohingya refugees are using social media for getting the latest news update, sharing an opinion (29.7\%), communicating with family and friends (24.3\%). $70.3 \%$ of respondents think social media is a positive thing, their favorite topics to see on social media are a personal story $(51.4 \%)$, and political facts $(32.4 \%)$. Finally, findings support that many paradigms of uses and gratifications theory are met by the Rohingya social media users.
\end{abstract}

Keywords: Rohingya refugee, Bangladesh, uses and gratification, social media, Facebook

\section{Introduction}

More than one million Rohingya refugee is living in Bangladesh right now (Uddin, 2017). The Rohingya, one of the most persecuted groups of people in the world, are being labeled as are persona non-grata, an unacceptable or unwelcome person by the numerous scholars from several countries of the world and treated inhumanely by the Myanmar authority since their independence in 1948. In August to October of 2017, around 750,00 Rohingya mostly Muslims fled Myanmar to avoid ethnic cleansing ("Rohingya refugees in Bangladesh," 2019) by Buddhist fundamentalists and the Myanmar army. They have no voice to rise against Myanmar's military junta's annihilation against them and have no leader to lead them properly. As a result, they have been slaughtered by the Buddhist fundamentalist and the army of Myanmar, since independence in January of 1948. Though the Rohingya are living in the Rakhine state of Myanmar for hundreds of years, in 1982 Myanmar citizen law did not recognize them as the citizen of Myanmar (Uddin, 2017). Now more than one million Rohingya refugees are living in the refugee camps of Ukhiya and Teknaf Upazila in Cox's Bazar district of Bangladesh.

In Myanmar, they had no access to higher education, proper medical treatment, and banking and were deprived of other government services. Though Bangladesh is providing them with food and medical treatment with the help of non-governmental organizations (NGOs), they are not providing educational services. Many NGOs from home and abroad are working to develop their living standards in the refugee camps by providing many life-related lessons. Somehow, the Rohingya people are using mobile phones and social media. This study conducted under the use and gratification theory. This study tried to find out why the Rohingya people use social media and how they gratify their needs. To work with the Rohingya is a bit challenging as very few of them understand English and have poor knowledge in standard Bangla, the official language of Bangladesh. Furthermore, their language has no written form. Due to the strict control of the Myanmar army over the Rohingya people, no study has been done about their social media uses in Myanmar. 
Now many scholars from Bangladesh and other countries are researching them by visiting Rohingya makeshift refugee camps in Bangladesh. The peer-reviewed literature on social media use by the Rohingya is not available right now. So, this study tends to relate to other studies from around the world conducted under the uses and gratification theory and social media uses of the refugees.

Uses and gratifications approaches suggest that individuals do make conscious choices about what they see and read in the media (Rayburn, 1996). By using social media, the Refugees are making it possible to maintain strong ties between the host society and the home country (Charmarkeh, 2013). "Refugees exercise their agency and enhance their well-being in ways that assist them to function effectively in a new society and regain control over their disrupted lives" (Andrade \& Doolin, 2016, p. 405). AbuJarour \& Krasnova (2017) speak that "social media and other information and communication technologies (ICTs) support promoting social inclusion of the refugees in their new homes" (p. 1792). So, this study expects to find out what the Rohingya refugee see on social media, what they read and how they communicate to gratify their needs as they have no formal/official written language.

\section{Literature Review}

\subsection{Uses and Gratification Theory}

In the field of communication and journalism, uses and gratification theory (UGT) is one of the major media effect theories. David (2016) defines "uses and gratification theory is an audience-centered approach that focuses on what people do with media, as opposed to what media do to people" (para. 1). Primary work of this theory started by Blumler and McQuail (1969) after the election in the United Kingdom in 1964. These authors characterized audience motivations for watching political programs during the election time. David (2016) points out "uses and gratifications theory seeks to understand why people seek out the media that they do and what they use it for" (para. 3). Under the UGT, media audiences counted as active media users who have the power and conscious to select what to use rather than treated as a passive consumer of media (David, 2016). UGT works on to find out how a person seeks out mass media to fulfill some specific needs or goals such as entertainment, relaxation or socializing (Blumler \& Katz, 1974; Katz, Blumler, \& Gurevitch, 1973). Today, individuals are connected with many modern communication gadgets and UGT becomes more relevant to how people gratify their needs via several multimedia devices.

Uses and gratification approaches believe that individuals do make conscious choices about what they see and read in the media (Rayburn, 1996). Though since the early 1940s, the use and gratification approach has been criticized on many grounds, it becomes a dominant paradigm in mass media research and has positioned as a major area of theoretical study for new media and integrated communications technologies. Rayburn (1996) argues that uses and gratifications may be the most promising theoretical area for the investigation of new media theories. Ball-Rokeach (1998), discusses the basic difference between Media System Dependency (MSD) and UGT. The author compared the assumptions, concepts, and propositions of MSD and UG theory at the micro-level of analysis. In brief, due to internet dependent relations, producer-consumer dependency relations are likely to change (Ball-Rokeach, 1998).

\subsection{Social Media Uses by the Refugees}

Dekker, Engbersen, Klaver, and Vonk (2018) address "social media offer a relatively cheap, easily accessible, and media-rich means of communication" (p. 1). Kutscher and Kreb (2016) argue, "Digital media are an important tool for refugees" (p. 200). Kutcher and Kreb (2016) examine "how unaccompanied minor refugees use digital media before, during, and after their flight" (p. 200). More specifically, "the authors seek to explore how young refugees used digital media to stay in contact with family, relatives, and friends in their country of origin and beyond, to establish new relationships, to orient themselves in the receiving country" (Kutcher \& Kreb, 2016, p. 201). The findings of Kutcher and Kreb (2016) indicate, "access to digital media presents a vital but contingent tool for young people in a trans-migratory context by enabling communication with family, peers, and supporters, promoting language appropriation, participation in education, and transitioning into the new society while maintaining connections with loved ones over great distances" (p. 202). Even one of the participants in this study mentioned "internet is the same like food" (Kutcher \& Kreb, 2016, p. 200)

Cheah, Karamehic-Muratovic, Matsuo, and Poljarevic (2011) examine "the role of language competence, interpersonal relationships, and media use in refugee resettlement using data from 315 Bosnians living in St. Louis, Missouri" (p. 217). Cheah et al. (2011) reveal that "host language competence, host and ethnic interpersonal relationships and media use, all positively contribute to refugees' adaptation" (p. 223). By studying the patterns of social media use before and during migration by the asylum migrants, Dekker et al. (2018) show "the majority of Syrian asylum migrants have access to social media information before and during migration, often through the use of smartphones" (p. 1). The Syrian asylum migrants favor social media information and they pondered it more trustworthy if the information is grounded on personal experiences (Dekker et al., 2018). Andrade and Doolin (2016) address "The social inclusion of newly resettled refugees is a significant issue confronting both refugees and their host societies" (p. 406). 


\subsection{Social Media Uses and Gratifications}

David (2016) reveals "UGT research into mobile phone usage has found that people seek several gratifications from their phones, including affection/sociability, entertainment, and mobility, among others" (para. 12). While using social media "users can be motivated by factors like a need to vent negative feelings, recognition, and cognitive needs" (David, 2016, para. 12). According to Ezumah (2013), college students use Social Media Network Sites (SMNSs) for numerous motives. These contain "keeping in touch with friends (98.9\%), sharing photos (81.7\%), keeping in touch with family (79.3\%), and entertainment (70.9\%)" (Ezumah, 2013, p. 27). Furthermore, "Facebook emerged as the preferred SMN site followed by Twitter, while LinkedIn was the least popular site among this group" (Ezumah, 2013, p. 27). This study strongly supports the basic notions of UGT. The study of Chen (2011) shows "the more hours per week the person spends on Twitter, the more the person gratifies a need for an informal sense of connection with other users" (p. 755). Additionally, the "frequency of tweeting and number of @replies, public messages between Twitter users, mediate the relationship between active Twitter use and gratifying a need for connection" (Chen, 2011, p. 755). Shao (2009) shows an individual uses social media in different ways for a different purpose. Furthermore, "they consume contents for fulfilling their information, entertainment, and mood management needs; they participate through interacting with the content and they produce their contents for self-expression and self-actualization" (p. 7).

Joo and Sang (2013) indicate that sharing news and experience on social media are the prime activities by Korean adult smartphone users. Raacke and Bonds-Raacke (2008) specify that "most college students are using these friend-networking sites for a significant portion of their day for reasons such as making new friends and locating old friends" (p.169). The study of Raacke and Bonds-Raacke (2008) shows very popular uses and gratification for having either account included "to keep in touch with old friends" (96.0\%), "to keep in touch with current friends" (91.1\%), "to post/look at pictures" (57.4\%), "to make new friends" (56.4\%), and "to locate old friends" (54.5\%). A factor analysis of gratifications obtained from Facebook revealed six key dimensions: pastime, affection, fashion, share problems, sociability, and social information (Quan-Haase \& Young, 2010). The study of Quan-Haase and Young (2010) disclose that "Facebook is about having fun and knowing about the social activities occurring in one's social network, whereas instant messaging is geared more toward relationship maintenance and development" (p. 350). Wang, Tchernev, and Solloway (2012) pronounce "social media use is significantly driven by all four categories of needs examined (emotional, cognitive, social, and habitual), but only gratifies some of them" (p. 1829). Cheung, Chiu, and Lee (2011) expose that "the use of social networks is strongly determined by social presence. Among the five values, social related factors had the most significant impact on the intention to use" (p. 1337). Shao (2009) bargains, over the last few years many user-generated media like YouTube, MySpace, and Wikipedia have become immensely popular.

Hicks, Comp, Horovitz, Hovarter, Miki, and Bevan (2012) indicate that "individuals overwhelmingly use Yelp.com for information-seeking purposes, followed by entertainment, convenience, interpersonal utility, and pass time" (p. 2274). Kim, Sohn, and Choi (2011) identify that seeking friends, social support, entertainment, information, and convenience are the major motives for using social network sites. Leung (2013) shows that "content generation using social media was satisfied with five socio-psychological needs: showing affection, venting negative feelings, gaining recognition, getting entertainment, and fulfilling cognitive needs" (p. 997). Park, Kee, and Valenzuela (2009) reveal that socializing, entertainment, self-status seeking, and information are the four needs for using Facebook groups. The findings of Dunne, Lawlor, and Rowley (2010) indicate that the participants actively use Bebo for their motives and gratifications in terms of presenting and managing a certain identity and persona in a social context. This study revealed six key dimensions: pastime, affection, fashion, share problems, sociability, and social information. Comparative analysis showed that Facebook is about having fun and knowing about social activities occurring in one's social network, whereas instant messaging is geared more toward relationship maintenance and development. Recent events indicate that sharing news on social media has become a phenomenon of increasing social, economic and political importance because individuals can now participate in news production and diffusion in large global virtual communities (Lee \& Ma, 2012).

Based on the literature discussed above this study set the following hypotheses and research questions.

H1: The Rohingya men spend more time than the Rohingya women on social media.

H2: The Rohingya people using social media for finding the latest news are more educated than the Rohingya people using social media for other reasons.

H3: The Rohingya people who like to see political stories on social media are more educated than Rohingya people who like to see other things on social media.

RQ1: What is the most favorite social media among the Rohingya refugee in Bangladesh?

RQ2: How long the Rohingya refugee use social media each day? 
RQ3: How long the Rohingya refugee use traditional media (newspaper, radio, TV) along with social media every day?

RQ4: How many social media accounts the Rohingya refugee use daily?

RQ5: When the Rohingya refugee started using social media?

RQ6: At what time the Rohingya refugee is the most active on social media?

RQ7: What is the attitude toward social media among the Rohingya refugee?

RQ8: What is the prime reason for using social media by the Rohingya refugee?

RQ9: In general, what is the favorite topic to see on social media by Rohingya refugees?

\section{Methods}

\subsection{Participants}

Among the respondents $(N=37)$, approximately $75 \%$ were male $(n=28)$, and $25 \%$ were female $(n=9)$ with an average age of $24.03(S D=4.09)$; the youngest reported being 19 years old while the oldest respondent reported being 32 years old. All respondents (100\%) reported Islam as their religion. The majority of the respondents (37.8\%) were born in Maungdaw, $35.1 \%$ of respondents were born in Rathedaung, and $27 \%$ of respondents were born in Buthidaung. About educational qualification, the majority of the respondents (48.6\%) reported having secondary school; around 19\% respondents reported having madrasa education (can read and understand Arabic and the Quran); 16.2\% respondents reported completing primary school; another $16.2 \%$ respondents reported having a degree from college.

\subsection{Procedure}

Data have been collected between April 1, 2019, and May 31, 2019, using a paper version questionnaire. All data collected in person by the researcher. The participants were recruited via a purposive sampling technique (Wimmer $\&$ Dominick, 2014) from four separate refugee blocks in Kutupalong refugee camps at Ukhiya. According to Wimmer and Dominick (2014), in purposive sampling "respondents, subjects, or elements selected for specific characteristics or qualities and eliminates those who fail to meet these criteria" (p.96). This author scrutinized the respondents whether they have a multimedia mobile phone with a data connection or not. The author helped the respondents to understand the questionnaire. Participation in the questionnaire were both anonymous and voluntary for the Rohingya refugees. After completing the data collection all data were inputted to excel sheet. Finally, data analysis and hypotheses testing were conducted by the SPSS software.

\subsection{Measure}

The questionnaire comprised of 17 questions that elicited both quantitative and qualitative data, the majority of the quantitative. This is a deliberate effort aimed at collecting rich data. Few qualitative questions allowed the respondents to write on the boxes if the suitable answers were not available on the questionnaire as opposed to pre-packaged responses. Follow-up questions also provided an opportunity for qualitative answers. For the quantitative section, prospective answers were given to keep the data manageable.

This study measured the most used social media by Rohingya refugee, amount of time spending on social media each day, their favorite topic on social media, the prime reason for using social media, attitude towards social media, most active time on social media, numbers of social media accounts they have, duration of using social media, time spending on traditional media. Demographic information on age, gender, religion, level of education, and birthplace were also included.

\section{Results}

H1 listed the Rohingya men spend more time than the Rohingya women on social media. An independent samples t-test (Stone, 2010) reveal that the Rohingya men $(M=2.82, S D=1.02)$ and Rohingya women $(M=2.22, S D=.83)$ did not spend significantly different amounts of time using social media; $t(35)=1.59, p=n . s$. Therefore, we fail to reject the null hypothesis.

H2 stated the Rohingya people using social media for finding the latest news are more educated than the Rohingya people using social media for other reasons. One-way Analysis of Variance with Student-Newman-Keuls (S-N-K) post-hoc test (Stoll, 2017) reveal that to find latest news $(M=2.42, S D=1.17)$, share opinion $(M=2.64, S D=1.03)$, connect with family and friends $(M=2.89, S D=.33)$, were almost equal to make new friends $(M=2.60, S D=1.34) ; F(3,36)=.38, p$ $=n . s$. Therefore, we fail to reject the null hypothesis.

H3 specified the Rohingya people who like to see political stories on social media are more educated than Rohingya people who like to see other things on social media. One-way Analysis of Variance with Student-Newman-Keuls (S-N-K) post-hoc test (Stoll, 2017) reveal that who like to see political story $(M=2.67, S D=.99)$, personal story or event $(M=$ 
2.63, $S D=.96)$, were almost equal to who like to see religious story $(M=2.50, S D=1.23) ; F(2,36)=.06, p=n . s$. Therefore, we fail to reject the null hypothesis.

RQ1 intended to find out the most favorite social media among the Rohingya refugee in Bangladesh? All 37 (100\%) respondents mentioned Facebook as their most favorite social media platform.

RQ2 proposed to see how long they use social media each day? Majority of them (32.4\%) spent four to five hours each day, around one-fourth (24.3\%) of the respondents consumed six to seven hours per day. A significant portion of them (29.7\%) spent two to three hours per day. Finally, only $13.5 \%$ of the Rohingya refugee used social media for less than one hour per day.

RQ3 projected to see how long they use traditional media (newspaper, radio, TV) along with social media every day? The findings revealed that the majority of them (37.8\%) used traditional media less than one hour per day. A significant number (29.7\%) of them did not use traditional media at all. Another $29.7 \%$ of them used traditional media for one to two hours each day. A very small portion of them (2.7\%) used traditional media for three to four hours per day.

RQ4 planned to reveal how many social accounts they use? A significant number $(62.2 \%)$ of the respondents had only one social media account, $24.3 \%$ of them had two accounts and only $13.5 \%$ of the Rohingya refugee had three accounts on different social media platforms.

RQ5 proposed to reveal when the Rohingya refugee started using social media? 29.7\% of respondents revealed that they were using social media for three to four years. The majority of them $(37.8 \%)$ were using social media for one to two years. A little number ((10.8\%) of them were using social media for less than one year.

RQ6 intended to find at what time the Rohingya refugee is the most active on social media? The majority (43.2\%) of the social media user replied they were most active on social media at 7-8 PM. 27\% were active at 9-10 PM, $16.2 \%$ were active after $10 \mathrm{PM}$ and a few of them (13.5\%) were active at 3-4 PM.

RQ7 anticipated knowing what is the attitude toward social media among the Rohingya refugee? The majority (70.3\%) of the respondents thought social media were a positive thing, $27 \%$ were treated social media as a negative thing, and $2.7 \%$ replied that they don't know/won't say.

RQ8 planned to see what is the prime reason for using social media by the Rohingya refugee? $32.4 \%$ of respondents replied that they were using social media to get the latest news, $29.7 \%$ replied to share their own opinion, $24.3 \%$ replied to connect with family and friends, and $13.5 \%$ replied to make new friends.

RQ9 proposed to see the favorite topic to see on social media by Rohingya refugees? The majority $(51.4 \%)$ of them think they like to see personal stories or events on social media. $32.4 \%$ of the users like political stories or facts and only $16.2 \%$ of the respondents like to see religious events story on social media.

\section{Discussion}

The main reasons for using social media by the Rohingya refugees in Bangladesh are "to find the latest news", "to share their own opinion", "to connect with family and friends", and "to make new friends" which strongly support the paradigms of uses and gratification theory (UGT). UGT is an audience-centered approach that focuses on what people do with media, as opposed to what media does to people. This study found that the Rohingya refugee in Bangladesh gratifies their cognitive needs by using social media. More than half of the respondents used social media for "personal reason", around one-third of them use social media for "political reason". Hypotheses testing revealed that there was no significant difference among the male and female for the duration of social media use each day, there was no significant difference among the user with various education levels and the purpose of using social media. Around one one-third of the respondents do not use traditional media (newspaper, radio, TV) at all along with social media. This study strongly supports many patterns of uses and gratifications theory.

\subsection{Limitations}

Like other studies in the field of media and communication, this study also has some limitations which are mentioned below:

a) The sample size was not big enough to represent the Rohingya refugees in Bangladesh. From more than one million refugees, there were only 37 respondents. This is a negligible sample size.

b) The study area was not adequate. The author only selected respondents from the Kutupalong refugee camps. But there are more camps in Ukhiya and Teknaf Upazila.

c) Respondents' selection was somehow biased. Before selecting them, the author had to talk to them whether they use social media and intended to participate in the survey.

d) The representative from other religions was absent and the participation of the women was not sufficient. 


\section{Conclusion}

Social media is the best medium to be connected with people locally and internationally. Thus, it becomes popular day by day. This study intended to address the nature and pattern of social media use by the Rohingya refugees in Bangladesh under the uses and gratification theory. Results indicate that Facebook is the most preferred social media. The majority of them (37.8\%) using social media for one to two years, $(43.2 \%)$ of them are most active on social media at 7-8 PM and spend four to five hours each day. $62.2 \%$ of the respondents have only one social media account. The majority (32.4\%) of the Rohingya refugees are using social media for getting the latest news update, share opinion (29.7\%), communicate with family and friends (24.3\%). $70.3 \%$ of respondents think social media is a positive thing, they spend time on social media for personal reasons (51.4\%), and political reasons (32.4\%). Finally, findings support that many paradigms of uses and gratifications theory are met by the Rohingya social media users.

\section{References}

AbuJarour, S., \& Krasnova, H. (2017). Understanding the role of ICTS in promoting social inclusion: the case of Syrian refugees in Germany. In Proceedings of the $25^{\text {th }}$ European Conference on Information Systems (ECIS), Guimarães, Portugal, June 5-10, 2017 (pp. 1792-1806). ISBN 978-989-20-7655-3 Research Papers. Retrieved from https://aisel.aisnet.org/ecis2017_rp/115

Andrade, A. D., \& Doolin, B. (2016). Information and communication technology and the social inclusion of refugees. MIS Quarterly, 40(2), 405-416. https://doi.org/10.25300/MISQ/2016/40.2.06

Ball-Rokeach, S. J. (1998). A Theory of media power and a theory of media use: Different stories, questions, and ways of thinking. Mass Communication \& Society, 1(1/2), 5-40. https://doi.org/10.1080/15205436.1998.9676398

Blumler, J. G., \& Katz, E. (1974). The Uses of mass communications: Current perspectives on gratifications research. Beverly Hills: Sage Publications.

Blumler, J. G., \& McQuail, D. (1969). Television in politics: Its uses and influence. Chicago: University of Chicago Press.

Charmarkeh, H. (2013). Social media usage, tahriib (migration), and settlement among Somali refugees in France. Refuge: Canada's journal on refugees, 29(1), 43-52.

Cheah, W. H., Karamehic-Muratovic, A., Matsuo, H., \& Poljarevic, A. (2011). The role of language competence, interpersonal relationships, and media use in Bosnian refugees' resettlement process. Journal of Intercultural Communication Research, 40(3), 219-236. https://doi.org/10.1080/17475759.2011.618842

Chen, G. M. (2011). Tweet this: A uses and gratifications perspective on how active Twitter use gratifies a need to connect with others. Computers in Human Behavior 27, 755-762. https://doi.org/10.1016/j.chb.2010.10.023

Cheung, C. M. K., Chiu, P. Y., \& Lee, M. K. O. (2011). Online social networks: Why do students use Facebook? Computers in Human Behavior, 27, 1337-1343. https://doi.org/10.1016/j.chb.2010.07.028

David, L. (January 26, 2016). Uses and gratification theory. Learning Theories. Retrieved from https://www.learning-theories.com/uses-and-gratification-theory.html

Dekker, R., Engbersen, G., Klaver, J., \& Vonk, H. (2018). Smart refugees: how Syrian asylum migrants use social media information in migration decision-making. Social Media Society, 4(1), 1-11. https://doi.org/10.1177/2056305118764439

Dunne, A., Lawlor, M. A., \& Rowley, J. (2010). Young people's use of online social networking sites: A uses and gratifications perspective. Journal of Research in Interactive Marketing, 4(1), 46-58. https://doi.org/10.1108/17505931011033551

Ezumah, B. A. (2013). College students' use of social media: site preferences, uses and gratifications theory revisited. International Journal of Business and Social Science 4(5), 27-34.

Hicks, A., Comp, S., Horovitz, J., Hovarter, M., Miki, M., \& Bevan, J. L. (2012). Why people use Yelp.com: An exploration of uses and gratifications. Computers in Human Behavior, 28, 2274-2279. https://doi.org/10.1016/j.chb.2012.06.034

Joo, J., \& Sang, Y. (2013). Exploring Koreans' smartphone usage: An integrated model of the technology acceptance model and uses and gratifications theory. Computers in Human Behavior 29, 2512-2518.

https://doi.org/10.1016/j.chb.2013.06.002

Katz, E., Blumler, J. G., \& Gurevitch, M. (1973). Uses and gratifications research. The Public Opinion Quarterly, 37(4), 509-523. https://doi.org/10.1086/268109

Kim, Y., Sohn, D., \& Choi, S. M. (2011). Cultural difference in motivations for using social network sites: A comparative 
study of American and Korean college students. Computers in Human Behavior, 27, 365-372. https://doi.org/10.1016/j.chb.2010.08.015

Kutscher, N., \& Kreb, L. M. (2016). "Internet is the same like food"-An empirical study on the use of digital media by unaccompanied minor refugees in Germany. Transnational Social Review, 6(1-2), 200-203. https://doi.org/10.1080/21931674.2016.1184819

Lee, C. S., \& Ma, L. (2012). News sharing in social media: The effect of gratifications and prior experience. Computers in Human Behavior 28, 331-339. https://doi.org/10.1016/j.chb.2011.10.002

Leung, L. (2013). Generational differences in content generation in social media: The roles of the gratifications sought and of narcissism. Computers in Human Behavior, 29, 997-1006. https://doi.org/10.1016/j.chb.2012.12.028

Park, N., Kee, K. F., \&Valenzuela, S. (2009). Being immersed in social networking environment: Facebook groups, uses and gratifications, and social outcomes. Cyber Psychology \& Behavior 12(6), 729-734. https://doi.org/10.1089/cpb.2009.0003

Quan-Haase, A., \& Young, A. L. (2010). Uses and gratifications of social media: A comparison of Facebook and instant messaging. Bulletin of Science, Technology \& Society, 30(5), 350-361. https://doi.org/10.1177/0270467610380009

Raacke, J., \& Bonds-Raacke, J. (2008). MySpace and Facebook: applying the uses and gratifications theory to exploring friend-networking sites. Cyber Psychology \& Behavior 11(2), 169-174. https://doi.org/10.1089/cpb.2007.0056

Rayburn, J. D. II (1996). Uses and Gratifications. In D. W. Salwen and M. B. Stacks (Eds.) An Integrated Approach to Communication Theory and Research (1996). Mahwah, NJ: LEA

Rohingya refugees in Bangladesh: Facts, FAQs, and how to help. (2019, August 27). Retrieved from https://www.worldvision.org/refugees-news-stories/rohingya-refugees-bangladesh-facts

Shao, G. (2009). Understanding the appeal of user-generated media: A uses and gratification perspective. Internet Research, 19(1), 7-25. https://doi.org/10.1108/10662240910927795

Stoll, A. (2017). Post hoc tests: student-newman-keuls test. In M. Allen (Ed.), The sage encyclopedia of communication research methods (pp. 1304-1304). Thousand Oaks, CA: SAGE Publications, Inc https://doi.org/10.4135/9781483381411.n451

Stone, E. (2010). T test, independent samples. In N. J. Salkind (Ed.), Encyclopedia of research design (pp. 1552-1556). Thousand Oaks, CA: SAGE Publications, Inc.

Uddin, R. N. (2017). Not Rohingya, but Royangya: Stateless people in the crisis of existence. Dhaka: Murdhonno.

Wang, Z., Tchernev, J. M., \& Solloway, T. (2012). A dynamic longitudinal examination of social media use, needs, and gratifications among college students. Computers in Human Behavior, 28, 1829-1839. https://doi.org/10.1016/j.chb.2012.05.001

Wimmer, R. D., \& Dominick, J. R. (2014). Mass Media Research: An Introduction (10th ed.). Boston: Wadsworth, Cengage Learning.

\section{Copyrights}

Copyright for this article is retained by the author(s), with first publication rights granted to the journal.

This is an open-access article distributed under the terms and conditions of the Creative Commons Attribution license which permits unrestricted use, distribution, and reproduction in any medium, provided the original work is properly cited. 